OPEN ACCESS

Edited by:

Carolina Escobar,

University of Castilla La Mancha,

Spain

Reviewed by:

Keith G. Davies,

University of Hertfordshire,

United Kingdom

Aurelio Ciancio,

Italian National Research Council,

Italy

*Correspondence: Holger Hever

holger.heuer@julius-kuehn.de

Specialty section:

This article was submitted to Plant Microbe Interactions,

a section of the journal

Frontiers in Plant Science

Received: 15 November 2019 Accepted: 29 January 2020

Published: 25 February 2020

Citation:

Topalović O, Bredenbruch S, Schleker ASS and Heuer H (2020) Microbes Attaching to Endoparasitic Phytonematodes in Soil Trigger Plant Defense Upon Root Penetration by the Nematode. Front. Plant Sci. 11:138 doi: $10.3389 /$ fpls.2020.00138

\section{Microbes Attaching to Endoparasitic Phytonematodes in Soil Trigger Plant Defense Upon Root Penetration by the Nematode}

\author{
Olivera Topalovic' ${ }^{1}$, Sandra Bredenbruch ${ }^{2}$, A. Sylvia S. Schleker ${ }^{2}$ and Holger Heuer ${ }^{1 *}$ \\ 1 Department of Epidemiology and Pathogen Diagnostics, Julius Kühn-Institut-Federal Research Centre for Cultivated \\ Plants, Braunschweig, Germany, ${ }^{2}$ Rheinische Friedrich-Wilhelms-University of Bonn, INRES-Molecular Phytomedicine, \\ Bonn, Germany
}

Root-knot nematodes (Meloidogyne spp.) are among the most aggressive phytonematodes. While moving through soil to reach the roots of their host, specific microbes attach to the cuticle of the infective second-stage juveniles (J2). Reportedly, the attached microorganisms affect nematodes and reduce their performance on the host plants. We have previously shown that some non-parasitic bacterial strains isolated from the cuticle of Meloidogyne hapla in different soils affected J2 mortality, motility, hatching, and root invasion. Here we tested whether cuticle-attached microbes trigger plant defenses upon penetration of $\mathrm{J} 2$. In in vitro assays, $M$. hapla J2-attached microbes from a suppressive soil induced pathogenassociated molecular pattern-triggered immunity (PTI) in tomato roots. All tested PTIresponsive defense genes were upregulated after root invasion of J2 with attached microbes, compared to surface-sterilized J2, particularly the jasmonic acid-mediated PTI marker genes TFT1 and GRAS4.1. The strain Microbacterium sp. K6, that was isolated from the cuticle, significantly reduced root invasion when attached to the J2. Attached K6 cells supported plant defense and counteracted suppression of plant basal defense in roots by invaded J2. The plant response to the J2-attached $\mathrm{K} 6$ cells was stronger in leaves than in roots, and it increased from 1 to 3 days post inoculation (dpi). At $1 \mathrm{dpi}$, the plant responded to J2-attached K6 cells by ameliorating the J2-triggered down-regulation of defense genes mostly in roots, while at 3 dpi this response was systemic and more pronounced in leaves. In a reactive oxygen species (ROS) assay, the compounds released from J2 with attached K6 cells triggered a stronger ROS burst in tomato roots than the compounds from nematodes without K6, or the metabolites released from strain K6 alone. Leaves showed a 100 times more sensitive response than roots, and the metabolites of $\mathrm{K} 6$ with or without $\mathrm{J} 2$ induced strong ROS bursts. In conclusion, our results suggest the importance of microorganisms that attach to M. hapla in suppressive soil, inducing early basal defenses in plants and suppressing nematode performance in roots.

Keywords: root-knot nematode, MAMP, pathogen-triggered immunity, induced systemic resistance, suppressive soil, antagonistic bacteria 


\section{INTRODUCTION}

Plant-parasitic nematodes feed on many crops worldwide and, if not maintained below the damage threshold in soil, they can cause enormous yield losses with an estimation of 100 billion dollars a year (Coyne et al., 2018). The genus Meloidogyne [rootknot nematodes (RKN)] has gained substantial attention in science based on the damage it causes to plants (Jones et al., 2013). The RKN infective second-stage juveniles (J2) enter the host roots at the elongation zone and, upon moving through the apoplast, inject effector proteins through a hollow stylet into the host cells to manipulate their functions and suppress plant defense (Sijmons et al., 1991; Gheysen and Mitchum, 2011). In the vascular cylinder, the effectors induce a repeated mitosis of the surrounding cells without cytokinesis, resulting in the formation of 5 to 7 giant cells that become permanent feeding sites of the nematode (Gheysen and Mitchum, 2011; Siddique and Grundler, 2018). Up to the formation of permanent feeding sites, RKN J2 do not cause huge damage during the migration phase in roots (Williamson and Hussey, 1996). It was shown that, unlike cyst nematodes, RKN do not activate damageassociated molecular pattern-triggered immunity (Shah et al., 2017), but cause expression of certain defense genes (Williamson and Hussey, 1996; Teixeira et al., 2016). Thus, they employ insidious strategies to reduce their recognition by plant. However, the life cycle of RKN can be disrupted by beneficial soil microorganisms that induce plant defenses (Adam et al., 2014a). Root border cells and root exudates play a crucial role in shaping the microbial communities in the rhizosphere, eventually resulting in a positive plant-soil feedback (Bertin et al., 2003; Bais et al., 2006; Doornbos et al., 2012; De-la-Peña and Loyola-Vargas, 2014; Ma et al., 2017). Evidence is accumulating that certain beneficial microorganisms suppress plant-parasitic nematodes by inducing systemic resistance (ISR) in plants (Reitz et al., 2000; Munif et al., 2001; Siddiqui and Shaukat, 2004; Dababat and Sikora, 2007; Adam et al., 2014b; Selim et al., 2014; Martínez-Medina et al., 2017b; Elhady et al., 2018; Kang et al., 2018; Silva et al., 2018; Topalović and Heuer, 2019). In the initial phase of microbially induced plant defense the pattern recognition receptors localized on the plant cell membranes recognize molecular structures on the microbe/ pathogen surface that are referred to as microbe/pathogenassociated molecular patterns (MAMP/PAMP) (Jones and Dangl, 2006). This leads to the activation of PAMP-triggered immunity (PTI) in plants, i.e. rapid release of reactive oxygen species (ROS) (Lamb and Dixon, 1997), callose deposition on the cell walls (Millet et al., 2010), mitogen-activated protein kinase (MAPK) signaling (Wu and Baldwin, 2010), and multiple transcriptional changes (Campos et al., 2014; Coninck et al., 2015). Phytohormones such as jasmonic acid (JA), ethylene, and salicylic acid (SA) orchestrate the plant defense responses often in an antagonistic manner (Pieterse et al., 2012), but their crosstalk seems to be essential to induce systemic resistance by beneficial microorganisms (Wees et al., 2008; Martínez-Medina et al., 2013; Martínez-Medina et al., 2017a). For instance, Martínez-Medina et al. (2017a) reported that the nematodeantagonistic fungus Trichoderma harzianum T-78 activates a higher expression of SA marker genes in the early stages of tomato infection by the RKN Meloidogyne incognita, but also inhibits the suppression of JA marker genes that are expressed in the absence of the fungus.

The idea for the current study came from the previous finding that a specific microbial portion attached to the cuticle of infective nematode stages in soils may induce a varying degree of suppressiveness against plant-parasitic nematodes (Adam et al., 2014b; Elhady et al., 2017). Recently, we have isolated bacterial strains attached to the J2 of the RKN Meloidogyne hapla in different soils, and showed their antagonistic effects against nematodes with respect to mortality, motility, and root invasion (Topalović et al., 2019). One of the soils that we used for the J2 incubation to isolate attached microbes was obtained from a glasshouse of Geisenheim University, in the southeastern part of Germany. Remarkably, the extracted microbiomes from this soil suppressed performance of two endoparasitic nematode species, M. hapla and Pratylenchus neglectus, on tomato plants (Topalović et al., 2020). In a split-root experiment with $M$. hapla, the microbiomes reduced nematode invasion by ISR in plants, while the progeny was reduced by ISR and a direct antagonism.

Based on the above, we aimed to test the hypothesis that nematode-attached microbes might induce defense reactions in plants when $M$. hapla penetrated the root. Either the associated microbes would release compounds from the cuticle of the nematode that would act as PAMP, or the J2-transmitted microbes are recognized by plant receptors to trigger PTI defense responses. To test these hypotheses, we compared the expression profiles of several PTI-responsive genes in tomato roots inoculated with $\mathrm{J} 2$ of $M$. hapla with and without attached microbes from the suppressive Geisenheim soil. In addition, we studied the ROS burst of tomato plants in response to J2 of $M$. hapla and their associated bacterial isolates. Finally, we studied the ability of J2-attached bacterial cells to induce changes in expression of PTI-like genes in tomato plants and to suppress J2 invasion into roots. Our results contribute to understanding the biological importance of the microbial attachment to the infective stages of endoparasitic nematodes and the ability of the nematode-attached microbiome to accelerate defense responses of the plant against further nematode attack.

\section{MATERIALS AND METHODS}

\section{Surface-Sterilization of $M$. hapla J2 and Incubation in Soil Suspension}

M. hapla J2 were extracted and surface-sterilized as previously described (Topalović et al., 2019). Briefly, eggs were extracted from egg masses on tomato roots using $1.5 \%$ sodiumhypochlorite and collected on $20 \mu \mathrm{m}$ sieves. The eggs were transferred to a modified Baermann tray to allow hatching of J2 over a seven-day period. Freshly hatched J2 were collected every day and stored at $4^{\circ} \mathrm{C}$ until surface sterilization. J2 were surface sterilized using $0.02 \% \mathrm{HgCl}_{2}$ for $2 \mathrm{~min}$, washed with sterile tap water, and incubated for $4 \mathrm{~h}$ in an antibiotic solution of 
$200 \mathrm{mg} \mathrm{l}^{-1}$ streptomycin sulfate, $25 \mathrm{mg} \mathrm{l}^{-1}$ rifampicin, and $10 \mathrm{x}$ Cell Culture Guard (PanReac AppliChem). After incubation, the $\mathrm{J} 2$ were extensively washed on a $5-\mu \mathrm{m}$ sieve with sterile tap water. They were incubated for 2 days at room temperature to recover after surface sterilization.

To allow microbial attachment to nematodes, the M. hapla $\mathrm{J} 2$ were incubated in soil suspensions of a $M$. hapla-suppressive soil from Geisenheim (sandy clay soil with $2.7 \%$ humus, $\mathrm{pH}$ $7.4,49^{\circ} 59^{\prime} 01^{\prime \prime} \mathrm{N}, 7^{\circ} 57^{\prime} 25.5^{\prime \prime} \mathrm{E}$; Topalović et al., 2020). The soil was sieved through a $1 \mathrm{~mm}$ sieve and $30 \mathrm{~g}$ of sieved soil was blended with $120 \mathrm{ml}$ of sterile tap water ( $10 \mathrm{~g}$ of soil with $2 \times 20$ $\mathrm{ml}$ ) for $1 \mathrm{~min}$ at a high speed (Stomacher ${ }^{\circledR} 80$, LAB SYSTEM). The suspension decanted from Stomacher bags, was then centrifuged for $5 \mathrm{~min}$ at $500 \mathrm{~g}$ to remove soil particles. The supernatant containing released soil microbes was sieved through a sterile $5-\mu \mathrm{m}$ sieve to remove native nematodes and retain larger particles. The flow through was centrifuged for 10 $\mathrm{min}$ at 5,000 $\mathrm{g}$ and the pellet was resuspended in $30 \mathrm{ml}$ sterile tap water. In $3 \mathrm{ml}$ of this suspension containing $10^{7} \mathrm{CFU} \mathrm{ml}^{-1}$ bacteria and $10^{4} \mathrm{CFU} \mathrm{ml^{-1 }}$ fungi, 2,000 surface-sterilized J2 were incubated in 6 -well plates overnight at $20^{\circ} \mathrm{C}$ on a shaker at $30 \mathrm{rpm}$. As a control, J2 were incubated in $3 \mathrm{ml}$ of sterile tap water. Both treatments were replicated 10 times. After incubation, loosely attached microbes were removed by washing the $\mathrm{J} 2$ on sterile 5 - $\mu \mathrm{m}$ sieves with $20 \mathrm{ml}$ of sterile tap water. The soil suspension was plated on R2A media (Merck, Germany) supplemented with $100 \mathrm{mg} \mathrm{l}^{-1}$ cycloheximide and potato dextrose agar (Merck, Germany) supplemented with $50 \mathrm{mg}^{-1}$ streptomycin-sulfate, to determine the number of cultivable bacteria and fungi, respectively. The $\mathrm{R} 2 \mathrm{~A}$ plates were kept at $28^{\circ} \mathrm{C}$ for 2 days and the potato dextrose agar plates at room temperature for seven days before counting the colony forming units.

\section{Incubation of $M$. hapla J2 With Microbacterium sp. K6}

The J2 were surface sterilized as described above. The isolation and identification of Microbacterium sp. isolate K6 were done previously (Topalović et al., 2019). Bacteria were grown in liquid LB media at $28^{\circ} \mathrm{C}$ overnight, short-spinned for $30 \mathrm{~s}$ and resuspended in sterile tap water. Around 2,000 J2 were incubated in $1 \mathrm{ml}$ of the bacterial suspension $\left(1.9 \cdot 10^{7} \mathrm{CFU}\right)$ in $1.5 \mathrm{ml}$ microtubes overnight. Loosely attached bacterial cells were removed by washing $\mathrm{J} 2$ on 5 - $\mu \mathrm{m}$ sieves with $20 \mathrm{ml}$ of sterile tap water.

\section{Inoculation of Nematodes to Tomato Plants Growing in Sterile Media}

Tomato seeds (Solanum lycopersicum cv. 'Moneymaker') were surface sterilized using $70 \%$ ethanol for $1 \mathrm{~min}$ and $2.5 \% \mathrm{NaOCl}$ for $3 \mathrm{~min}$. They were washed with sterile water and air-dried. The seeds were planted in MS media (Murashige Skoog, Duchefa Biochemie) supplemented with 2\% Gelrite (Duchefa Biochemie) at $\mathrm{pH}$ 5.7. The plates with tomato seeds were kept in a climate chamber at $20^{\circ} \mathrm{C}$ with a $16 \mathrm{~h}$ photoperiod (Panasonic Versatile Environmental Test Chamber MLR-352H). To study if J2- attached microbes from soil suspension trigger expression of PTI-responsive genes in tomato roots, $350 \mathrm{~J} 2$ either with or without attached microbes were inoculated in a $10-\mu$ drop at the root base and tip. Control plants were inoculated with $10 \mu \mathrm{l}$ of sterile tap water. The plates (10 biological replicates) from each treatment were kept in a climate chamber for 3 days to let the J2 penetrate the roots. Similarly, to study whether attached bacterial cells of the strain K6 trigger expression of PTI-responsive genes in tomato leaves and roots, plants were inoculated with $350 \mathrm{~J} 2$ with or without attached bacterial cells as described above. In this experiment, each treatment was replicated twenty times and kept in a climate chamber for 1 or 3 days, respectively. Additional four replicates in each treatment were used to microscopically determine the number of invaded $\mathrm{J} 2$ in roots at 7 days post inoculation (dpi) after staining with acid fuchsin (Sigma Aldrich). For both experiments, small labeled bags were prepared from aluminium foil to quickly sample and freeze plants for RNA extraction. Using forceps, whole plants were carefully removed from the plates and adhering Gelrite was swiftly removed with a paper tissue. The plants were transferred to the bags, which were closed, immersed in liquid $\mathrm{N}_{2}$, and then stored at $-80^{\circ} \mathrm{C}$ until RNA extraction.

\section{RNA Extraction and cDNA Synthesis}

Frozen roots and leaves were transferred to separate $2 \mathrm{ml}$ microtubes and pulverized with a $5 \mathrm{~mm}$ metal bead in a TissueLyser II (Qiagen) twice for $20 \mathrm{~s}$ at the highest speed (30 $\mathrm{Hz}$ ), keeping samples frozen in a pre-cooled block. Total RNA from plants was extracted using the FastRNA Pro Green Kit (MP Biomedicals). Briefly, $1 \mathrm{ml}$ of RNApro solution was added to each tube and mixed well by inverting the tubes and pipetting to inactivate RNases and start chemical cell lysis. The suspension was transferred to a bead-beating tube and cells were mechanically lysed in a FastPrep-24 instrument (MP Biomedicals) for $35 \mathrm{~s}$ at speed level $6.0 \mathrm{~m} \mathrm{~s}^{-1}$. After centrifugation at $4^{\circ} \mathrm{C}$ for $5 \mathrm{~min}$ at $14,000 \mathrm{~g}, 800 \mu \mathrm{l}$ of the supernatant was extracted with $300 \mu \mathrm{l}$ chloroform by vortexing for $10 \mathrm{~s}$ and incubation at room temperature for $5 \mathrm{~min}$. After phase separation at $14,000 \mathrm{~g}$ for 5 min at $4^{\circ} \mathrm{C}$, the aqueous phase was transferred to a new tube. RNA was precipitated by adding $500 \mu \mathrm{l}$ cold absolute ethanol, inverting the tubes five times and incubation at $-20^{\circ} \mathrm{C}$ for $30 \mathrm{~min}$. The RNA was pelleted by centrifugation at $4^{\circ} \mathrm{C}$ for $15 \mathrm{~min}$ at $14,000 \mathrm{~g}$ and washed with $500 \mu \mathrm{l}$ cold RNase-free $70 \%$ ethanol. The RNA was resuspended in $30 \mu \mathrm{l}$ of RNase-free water (Invitrogen) and kept at $-80^{\circ} \mathrm{C}$ until use. Remaining traces of DNA were removed from aliquots of $1 \mu \mathrm{g}$ RNA by DNase I digestion followed by DNase inactivation and removal, using the DNA-free DNA Removal Kit (ThermoFisher Scientific). Purified RNA was reverse transcribed using Superscript IV according to the manufacturer's instructions (ThermoFisher Scientific). Briefly, $8 \mu \mathrm{l}$ RNA (ca. $1 \mu \mathrm{g}$ ) were incubated with $1 \mu \mathrm{l} 50 \mu \mathrm{M}$ oligo dT(23), $1 \mu \mathrm{l}$ dNTP $(10 \mathrm{mM}$ each) and $3 \mu \mathrm{l}$ nuclease-free water at $65^{\circ} \mathrm{C}$ for $5 \mathrm{~min}$ and on ice for at least $1 \mathrm{~min}$. Superscript IV (200 U in $1 \mu \mathrm{l}), 4 \mu \mathrm{l} 5 \times$ SSIV Buffer, $1 \mu \mathrm{l}$ $100 \mathrm{mM}$ DTT, and $1 \mu \mathrm{l}$ RNase OUT were added and cDNA synthesized at $55^{\circ} \mathrm{C}$ for $10 \mathrm{~min}$. Samples were heated to $80^{\circ} \mathrm{C}$ for 10 min and stored at $-20^{\circ} \mathrm{C}$. 


\section{Real-Time qPCR Analysis of Defense Gene Expression}

Real-time amplifications were performed using a CFX Connect Real Time Detection System (Bio-Rad) in $20 \mu \mathrm{l}$ reactions containing Standard Taq Reaction Buffer (New England BioLabs), $0.25 \mathrm{mM} \mathrm{MgCl}_{2}, 0.2 \mathrm{mM}$ of each dNTP, $2 \times$ EvaGreen (Biotium), $1 \mu \mathrm{M}$ of gene specific primers (Table 1), and 0.5 U Hot Start Taq DNA Polymerase (New England BioLabs). Thermocycles were as follows: initial denaturation at $94^{\circ} \mathrm{C}$ for $5 \mathrm{~min}, 40$ cycles of a denaturation step at $94^{\circ} \mathrm{C}$ for $20 \mathrm{~s}$, annealing step at $60^{\circ} \mathrm{C}$ for $30 \mathrm{~s}$, an extension step at $68^{\circ} \mathrm{C}$ for $30 \mathrm{~s}$, and $80^{\circ} \mathrm{C}$ for $30 \mathrm{~s}$. The fluorescence was read at the $80^{\circ} \mathrm{C}$ step of each cycle. After each run, a melting curve was generated between $65^{\circ}$ and $95^{\circ} \mathrm{C}$. Ct values of defense genes were normalized to the ubiquitin gene expression, and their relative expressions in each sample were determined against gene expressions in control plants without nematodes, using the $2^{-\Delta \Delta C t}$ method (Pfaffl, 2001).

\section{Real-Time qPCR Analysis of Meloidogyne $18 S$ rRNA in CDNA of Roots}

Relative quantification of the $18 \mathrm{~S}$ rRNA gene of $M$. hapla inside tomato roots infested with $\mathrm{J} 2$ with and without attached K6 strain were determined using $5 \mu \mathrm{l}$ of cDNA samples. A $750 \mathrm{bp}$ fragment of the M. hapla $18 \mathrm{~S}$ rRNA of invaded J2 in roots was amplified in real-time qPCR using a CFX Connect Real Time Detection System (Bio-Rad) in $25 \mu \mathrm{l}$ reactions containing Standard Taq Reaction Buffer (New England BioLabs), $0.25 \mathrm{mM} \mathrm{MgCl}_{2}, 0.2 \mathrm{mM}$ of each $\mathrm{dNTP}$, EvaGreen (Biotium), $1 \mu \mathrm{M}$ of Meloidogyne spp. specific primers Melolf (5'-AAGATATCTGGTTGATCCTGCCTGA-3') and Melo723r (5'-GTTCAAAGTAAACTTGCAAYGMCTG-3'), 0.625 U Hot Start Taq DNA Polymerase (New England BioLabs). After initial denaturation at $94^{\circ} \mathrm{C}$ for $2 \mathrm{~min}$, fragments were amplified in 40 cycles with a denaturation at $94^{\circ} \mathrm{C}$ for $20 \mathrm{~s}$, annealing at $57^{\circ} \mathrm{C}$ for $20 \mathrm{~s}$, extension at $72^{\circ} \mathrm{C}$ for $45 \mathrm{~s}$, and fluorescence detection at $80^{\circ} \mathrm{C}$ for $30 \mathrm{~s}$. Melting curves were generated between $65^{\circ}$ and $95^{\circ} \mathrm{C}$. Ct values were normalized to the ubiquitin gene expression, and $18 \mathrm{~S}$ rRNA of J2 with attached bacterial strain K6 were determined relative to $18 \mathrm{~S}$ rRNA of J2 without K6 using the $2^{-\Delta \Delta C t}$ method (Pfaffl, 2001).

\section{ROS Burst Assay}

The Microbacterium sp. isolate K6 and Acinetobacter sp. isolate E1 were obtained in a previous study (Topalović et al., 2019).
Around 10,000 surface sterilized J2 of M. hapla were incubated in $200 \mu \mathrm{l}$ suspensions of the strains K6 or E1 $\left(10^{7}\right.$ $\mathrm{CFU} \mathrm{ml} \mathrm{m}^{-1}$ ), or $200 \mu \mathrm{l}$ of sterile tap water in $1.5 \mathrm{ml}$ microtubes, at room temperature overnight without shaking. The bacterial suspensions were prepared as described previously (Topalović et al., 2019). The supernatants were sterile-filtered the following day and served as the surface-released compounds from the J2 (SC) with and without bacterial cell-free supernatants. The J2-bacteria pellets were suspended in 200 $\mu \mathrm{l}$ of sterile tap water to get suspensions of live J2 with and without the living bacteria.

To measure ROS burst we adapted previously published methods (Prince et al., 2014; Mendy et al., 2017). Briefly, the cotyledon leaves were excised from 12-days-old tomato plants and incubated in $\mathrm{ddH}_{2} \mathrm{O}$ in the dark for $12 \mathrm{~h}$. The leaf samples were then transferred to a 96 -well plate that contained $80 \mu \mathrm{l}$ of $0.1 \mu \mathrm{M}$ luminol derivate 8-amino-5-chloro-2,3-dihydro-7phenyl-pyrido[3,4-d] pyridazine sodium salt (L-012, Wako Chemicals). After another hour of incubation in the dark, 20 $\mu \mathrm{l}$ of $20 \mu \mathrm{g} \mathrm{ml}^{-1}$ horseradish peroxidase was added to each well followed by $50 \mu \mathrm{l}$ elicitor, with $1 \mu \mathrm{M}$ flagellin peptide (Flg22) as positive and sterile tap water as negative controls. The elicitor treatments were as follows: (a) Live J2, (b) SC, (c) Live J2 + K6 cells, (d)SC + K6 cell-free supernatant, (e) Live J2 + E1 cells, (f) SC + E1 cell-free supernatant. The assay was repeated three times with three technical replicates each. Relative light units of luminescence were measured in a 96-well microplate reader (Infinite ${ }^{\circledR} 200 \mathrm{PRO}$; TECAN) over $120 \mathrm{~min}$. The data were analyzed using instrument software and Microsoft Office Excel.

\section{Statistical Analysis}

Fold changes in expression of each defense gene after root penetration of $\mathrm{J} 2$ with or without attached microbes, as related to expression without nematodes, were log-transformed to better fit linear models (smaller AIC). Generalized linear models were applied using the statistical software SAS 9.4. Class variables were MICROBES $(1,0)$ and GENE (GRAS4.1, MPK1, PDF1.2, PR1a1, TFT1, WRKY28) for the experiment with attached microbiome from Geisenheim soil, and additionally DPI $(1,3)$ and TISSUE (leaf, root) for the experiment with the attached bacterial strain K6. A post hoc Tukey-test was done to compare fold changes in expression of defense genes in plants invaded by $\mathrm{J} 2$, with or without attached microbes.

TABLE 1 | Primer pairs used in this study.

\begin{tabular}{|c|c|c|c|}
\hline Gene & Forward primer $\left(5^{\prime}-3^{\prime}\right)$ & Reverse primer $\left(5^{\prime}-3^{\prime}\right)$ & Reference \\
\hline PR1a1 & CTGGTGCTGTGAAGATGTGG & TGACCCTAGCACAACCAAGA & Harel et al., 2014 \\
\hline PDF1.2 & GGCTAGCAAAATCACTITCTGTG & CATGATCCTTATIITGCACCA & Tran et al., 2017 \\
\hline GRAS4.1 & TTCGAATCCССTGCTTCCAT & CCAGTTGGTGAATTGCTGCT & This study \\
\hline MPK1 & GCTGACAGATTGTTGCAGGT & TCCACCCCATAAAGATACATCA & Kandoth et al., 2007 \\
\hline WRKY28 & ACAGATGCAGCTACСTCATCCTCA & GTGCTCAAAGCCTCATGGTTCTTG & Taylor et al., 2012 \\
\hline TFT1 & GCCTCGTCCATCTGCTCCTG & GAATGCATCAGAAAAAGCATGCAG & Taylor et al., 2012 \\
\hline PTI5 & ATTCGCGATTCGGCTAGACATGGT & AGTAGTGCCTTAGCACCTCGCATT & Taylor et al., 2012 \\
\hline Ubiquitin & GTGTGGGCTCACCTACGTाT & ACAATCCCAAGGGTTGTCAC & Bhattarai et al., 2008 \\
\hline Meloidogyne 18S rRNA & AAGATATCTGGTTGATCCTGCCTGA & GTTCAAAGTAAACTTGCAAYGMCTG & This study \\
\hline
\end{tabular}




\section{RESULTS}

\section{J2-Attached Microbes From Geisenheim Soil Trigger Expression of PTI-Responsive Genes in Tomato Roots}

To study if the microbiome attaching to the pre-infective J2 of $M$. hapla in Geisenheim soil induce PTI responses in tomato plants, the J2 were incubated in microbial suspensions overnight, washed, and nematodes with or without attached microbial cells were inoculated to 2 -week old tomato plants growing in MS media. The differential expression of six PTI marker genes 3 dpi was determined compared to their expression in roots without invaded nematodes. All tested PTI marker genes were expressed in the roots infested with both, clean juveniles and juveniles carrying the attached soil microbes. However, the J2 with attached microbes triggered PTI responses higher than those of the surface-sterilized J2 alone (Figure 1). Overall, ANOVA revealed a significant effect of attached microbes on defense gene expression $(P=0.001)$. The response of the genes to J2 differed $(P=0.0001)$, while the interaction of GENE * MICROBES was not significant $(P=0.55)$. The average upregulation of the plant defense genes by $\mathrm{J} 2$ with attached microbes was two-fold. However, data showed that J2 without attached microbes managed to down-regulate most of the defense genes (GRAS4.1, MPK1, PR1a1, TFT1), and that attached microbes counteracted this. The transcription factor
GRAS4.1 was significantly up-regulated 3 dpi when the roots were invaded by $\mathrm{J} 2$ with microbes attached to the cuticle, while in the absence of attached microbes this gene was repressed by the J2 $(P=0.002$, Tukey test $)$. Conversely, the transcription factor TFT1 was down-regulated in both treatments, but the downregulation was ameliorated by microbes attached to J2 $(P=0.035$, Tukey test). Although microbial attachment to the J2 of M. hapla in Geisenheim soil led to the up-regulation of both the transcription factor WRKY28 and the JA-regulated PDF1.2 defensin gene, this was not statistically supported. Mitogenactivated protein kinase 1 gene $(M P K 1)$ and the marker gene of the SA pathway (PR1a1) were both down-regulated with minor differences between the two treatments. Independent soil sampling and incubation of $\mathrm{J} 2$ confirmed the effect of J2attached microbes on defense gene expression. However, TFT1 was significantly up-regulated by the attached microbes while down-regulated without microbes (Supplementary Figure S1).

\section{Attachment of Bacterial Isolate $\mathrm{K} 6$ to $M$. hapla J2 Affected Root Invasion and Expression of PTI Marker Genes}

The bacterial strain Microbacterium sp. K6 was isolated from the nematode cuticle after baiting of J2 in Geisenheim soil suspension. The effect of this strongly attaching strain on plant defense upon root penetration of M. hapla J2 was investigated. The expression profiles of six PTI-responsive genes were

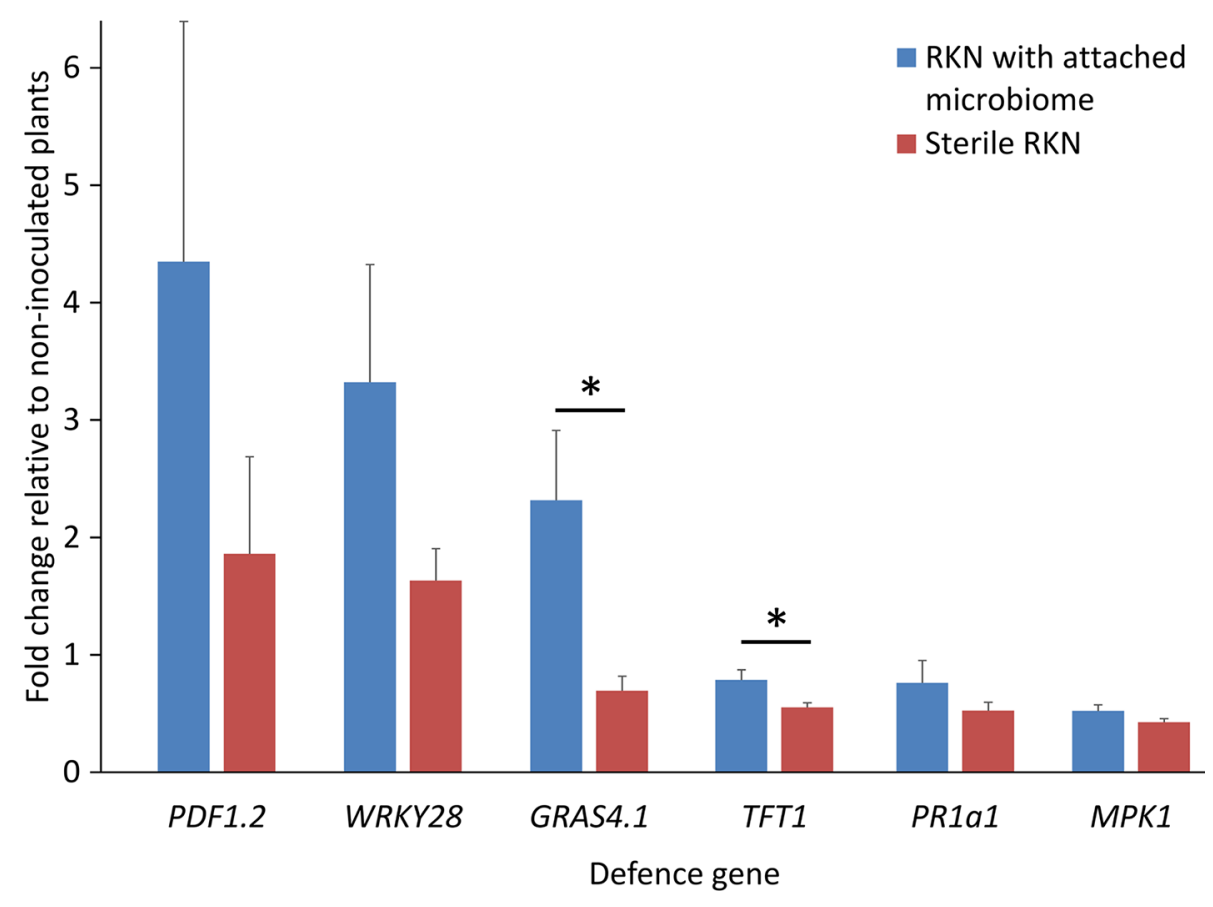

FIGURE 1 | Expression profiles of PTI-like genes in tomato roots in response to root penetrating juveniles of the root-knot nematode (RKN) Meloidogyne hapla with and without attached microbes from suppressive Geisenheim soil, 3 dpi. ANOVA by generalized linear models (see Supplement Statistics 1) revealed that the attached microbes significantly enhanced defense gene expression overall $(P=0.001)$, while the response of the various genes differed $(P=0.0001)$. Lines under an asterisk indicate significant differences between plants after invasion of nematodes with or without microbes attached to the cuticle $(P<0.05$, Tukey test on logtransformed data). Error bars represent SE ( $\mathrm{n}=10$ plants). 
determined in roots and leaves of 2 -week old tomato plants, 1 and 3 days after root inoculation of $\mathrm{J} 2$ with or without attached cells of strain K6 (Figure 2). Defense gene expression of invaded plants relative to uninoculated plants was normalized for ubiquitin transcripts. As the number of $\mathrm{J} 2$ invading the root and triggering plant defenses is reduced by strain K6, the defense gene expression was also adjusted to equal $M$. hapla $18 \mathrm{~S}$ rRNA in roots. ANOVA showed that the attached bacteria significantly enhanced defense gene expression $(P<0.0001)$. At $1 \mathrm{dpi}$, four of the defense genes were down-regulated in roots by invading J2 (Figure 2). Attached K6 resulted in less down-regulation and in significant up-regulation of the mitogen-activated protein kinase 1 gene $(M P K 1)$ in roots. In leaves at $1 \mathrm{dpi}$, only a weak response of defense genes to J2 invasion in roots was detectable. J2attached $\mathrm{K} 6$ resulted in a slightly higher expression of four of the defense genes, but a down-regulation of PR1a1. At $3 \mathrm{dpi}$, all six defense genes showed higher expression in roots and leaves in response to J2 with attached K6 compared to surface-sterilized J2. The attached bacteria caused a significant up-regulation of the PTI-genes in leaves and of the transcription factor WRKY28 in roots, while surface-sterilized J2 kept PTI defense at a low level (Figure 2). WRKY28 was down-regulated $1 \mathrm{dpi}$ and up-regulated 3 dpi in both treatments, while the K6 cells significantly increased the up-regulation of this gene $(P<0.0001$; Tukey test). In the ANOVA, the factors DPI and TISSUE had significant effects, and the effect of attached K6 was more pronounced 3 dpi than 1 dpi $(P=0.002$ for the interaction effect K6 * DPI). Overall, the genes WRKY28, GRAS4.1, and $M P K 1$ in roots, and $M P K 1$ in leaves were significantly triggered by $\mathrm{J} 2$-attached bacteria $(P<0.05$, Tukey correction).

To follow the effects of J2-attached K6 cells on nematode penetration, we determined the $18 \mathrm{~S}$ rRNA of $M$. hapla in the same root samples that were used to study expressions of defense genes. The number of $18 \mathrm{~S}$ rRNA increased from 1 to $3 \mathrm{dpi}$. The relative abundance of ribosomal RNA of J2 with attached K6 cells was $82 \%( \pm 22 \% \mathrm{SE})$ and $55 \%( \pm 15 \% \mathrm{SE})$, of the relative abundance of the J2 without attached bacterial cells at 1 and 3 dpi, respectively. The reduction became statistically significant at 3 dpi ( $P=0.018$, one sample t-test). With plants grown in parallel that were not sampled for RNA extraction, the number of J2 in roots was determined microscopically $7 \mathrm{dpi}$ (Figure 3). The nematode penetration was significantly suppressed by the attached K6 cells. The number of invaded J2 in control roots was the double of those with attached K6 cells. Thus, constantly less J2 invaded the roots within the first seven days after inoculation, when bacterial cells were attached to the cuticle.

\section{ROS Response of Tomato Tissue to $M$. hapla J2 With and Without Attached Bacteria}

We tested whether PTI is triggered in tomato plants by living bacterial cells of Microbacterium sp. K6 and Acinetobacter sp. E1,
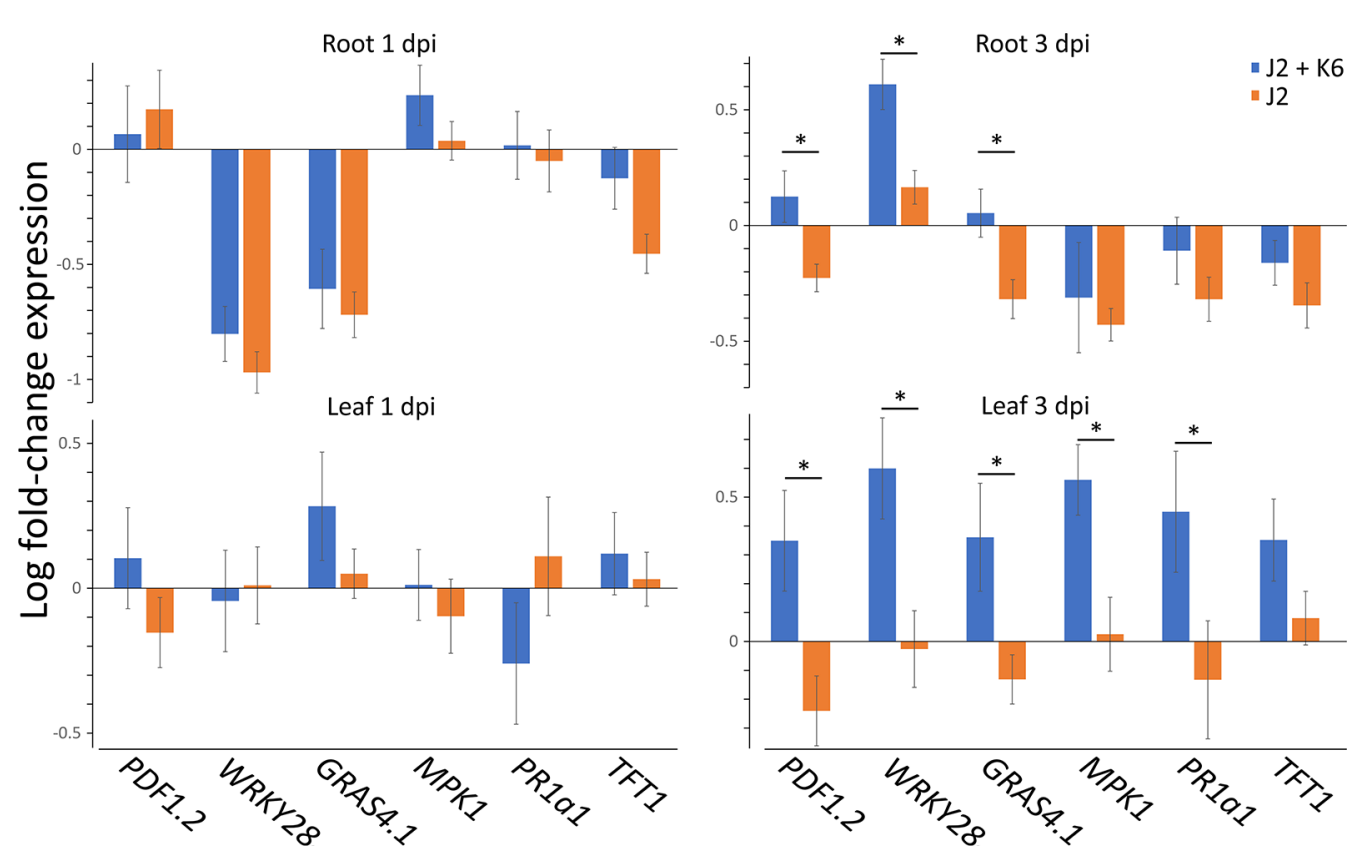

FIGURE 2 | Expression profiles of PTI genes in leaves and roots of tomato plants in response to M. hapla J2 with and without attached Microbacterium sp. K6. Defense gene expression of invaded plants relative to not inoculated plants, as determined in cDNA by Real-Time PCR, was normalized for ubiquitin transcripts and M. hapla 18S rRNA in roots, using the $2^{-\Delta \Lambda \mathrm{Ct}}$ method. Bars show means of log-transformed fold-changes in gene expression, one and three days after J2 inoculation to the roots (dpi). ANOVA by generalized linear models (see Supplement Statistics 2) revealed that the attached bacteria K6 (stages: with, without) significantly enhanced defense gene expression overall $(P$ $<0.0001$ ). The factors DPI (stages: $1 \mathrm{dpi}, 3 \mathrm{dpi}$ ) and TISSUE (stages: root, leaf) had significant effects on gene expression. The effect of attached K6 was more pronounced 3 dpi than $1 \mathrm{dpi}(P=0.002$ for the interaction effect K6 * DPI). Error bars represent SE ( $\mathrm{N}=10$ plants). 


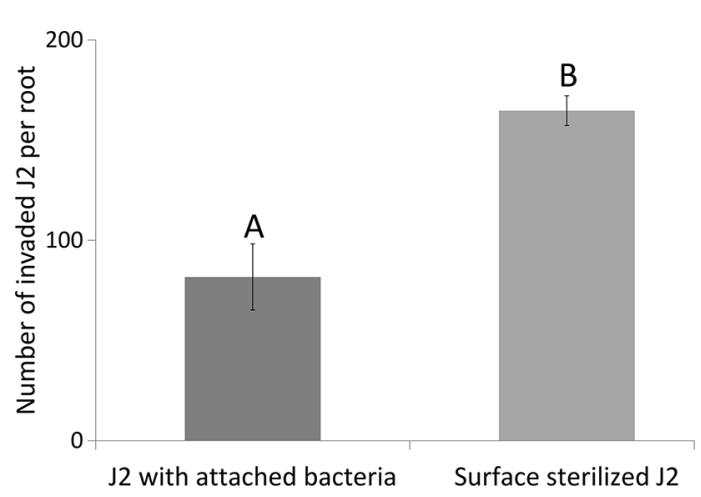

FIGURE 3 | Number of invaded J2 of $M$. hapla J2 in tomato roots 7 dpi, with or without attached Microbacterium sp. K6. Error bars represent SD. The letters above error bars indicate a significant difference between treatments $(P<0.05$, Tukey test; $\mathrm{n}=4$ plants). or by the compounds they release, or by the compounds that are released when $\mathrm{J} 2$ and bacteria are incubated together. The ROS patterns of leaves and roots of tomato plants were analyzed in response to the organisms and their surface-released compounds (SC), using a luminescence assay. To produce SC, nematodes and bacteria were incubated in water overnight alone or in combination, and the supernatant containing SC was separated from the organisms by centrifugation. Although all variants, living bacterial cells as well as their SC, nematodes and their SC, the live nematodes together with bacteria, and the SC from nematodes incubated with bacteria triggered a ROS peak in leaves within 25 min, differences were observed in their respective intensities (Figure 4). Both the SC from J2 and living J2 triggered a clear ROS burst, which was further amplified for variants including K6 or E1. Also in the absence of M. hapla, compounds of both bacterial strains were capable to elicit a strong ROS burst in the leaf tissue, while only the living cells of K6 induced a similar ROS pattern (Figure 4). Consequently, incubation with K6 or E1 led to

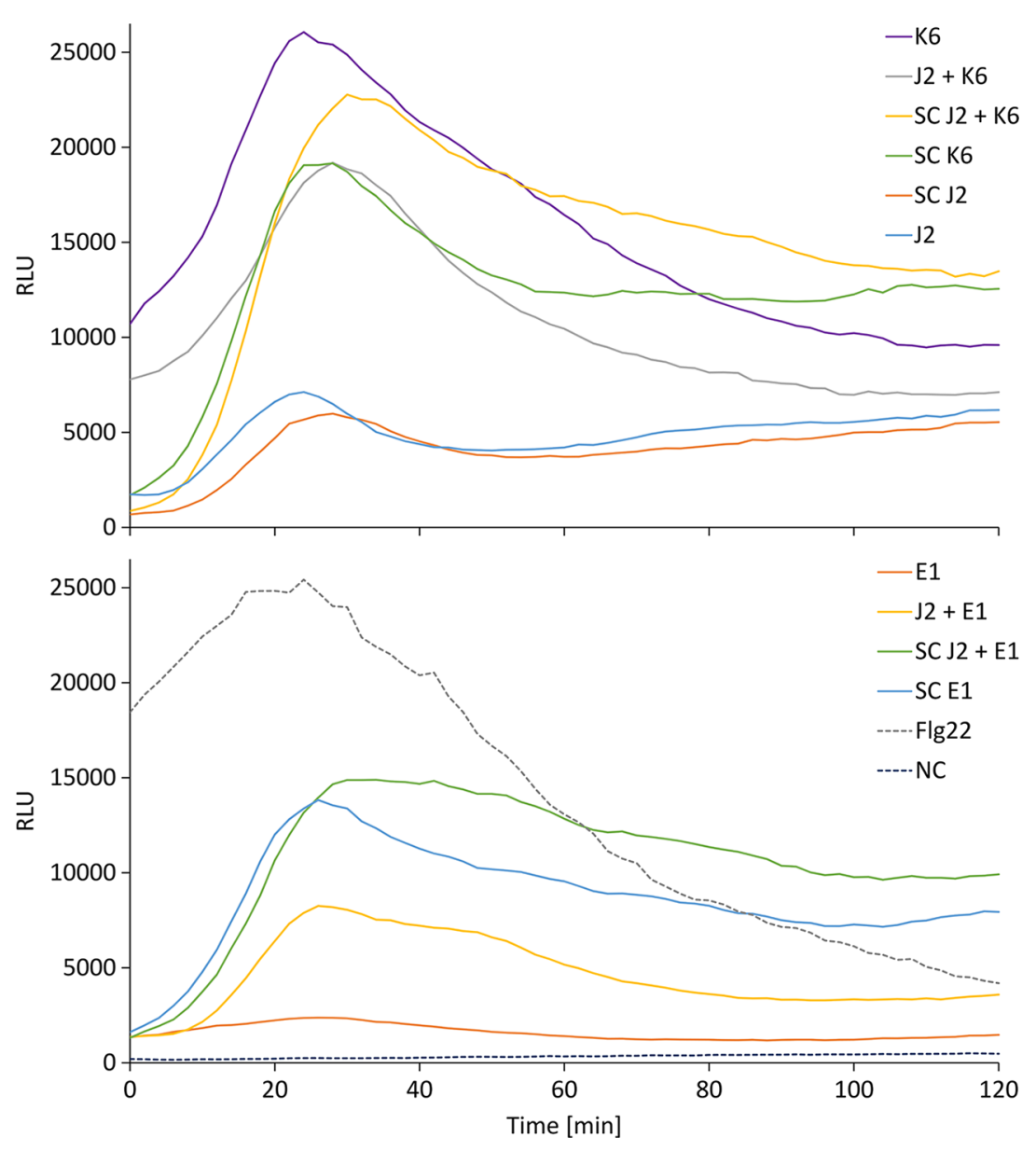

FIGURE 4 | Relative luminescence units (RLU) representing the ROS burst in tomato leaves over time for the different treatments. Treatments were K6: cells of Microbacterium sp. K6; J2 + K6: live juveniles of M. hapla (J2) + cells of K6; SC J2 + K6: released compounds from J2 incubated with K6; SC K6: released compounds from K6; SC J2: released surface compounds from J2; J2: live juveniles of $M$. hapla E1: cells of Acinetobacter sp. E1; J2 + E1: live juveniles + cells of Acinetobacter sp. E1; SC J2 + E1: released compounds from J2 incubated with E1; SC E1: released compounds from E1; Flg22: positive control; NC: water as negative control. Curves show means of 6 to 12 plants. 
an intensified ROS response to the infective stage of the parasitic nematode and related SC (Figure 4). The compounds released from $\mathrm{K} 6$ and $\mathrm{E} 1$ were sufficient to induce a strong ROS burst in the leaf tissue (Figure 5). Also the SC from M. hapla J2 triggered a considerable ROS burst. The SC from J2 that were incubated with $\mathrm{K} 6$ or E1 showed a trend to induce a stronger ROS response than the SC from the respective bacteria alone, although not statistically significant (Figure 5). The sum of the signals from the SC of $M$. hapla $\mathrm{J} 2$ and the SC of bacteria were not more than the ROS signal from the combined treatments obtained in leaves (Figure 5). In roots, similar reactions were observed but at 100 times lower intensity (Supplementary Figures S2, S3). The SC of strain K6 triggered not significantly more ROS than SC of M. hapla J2, while the SC from J2 incubated with strain K6 induced a significantly stronger ROS burst in roots than SC of both organisms alone (Figure 6). In contrast, for strain E1 the effect of its SC did not differ from the effect of the SC from $\mathrm{J} 2+\mathrm{E} 1$ that were incubated together.

\section{DISCUSSION}

DNA-based analysis of the microbiome associated with phytonematodes has gained attention over the recent years

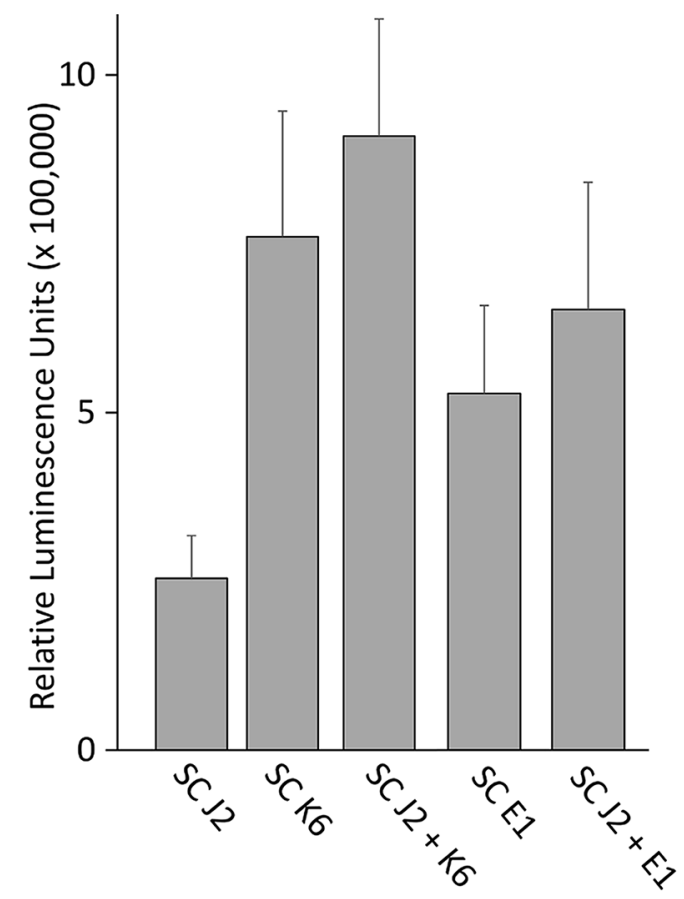

FIGURE 5 | ROS burst in tomato leaves triggered by surface-released compounds (SC) from juveniles of $M$. hapla (J2), bacteria isolated from the cuticle of J2 (Microbacterium sp. K6, Acinetobacter sp. E1), or J2 incubated with these bacteria. The sum of relative luminescence units over $2 \mathrm{~h}$ in a ROS assay with tomato leaves is shown. Differences among treatments were not significant $(P<0.05$, Tukey test on log-transformed data). Error bars represent $\mathrm{SE}$ ( $\mathrm{n}=6$ to 12 plants).

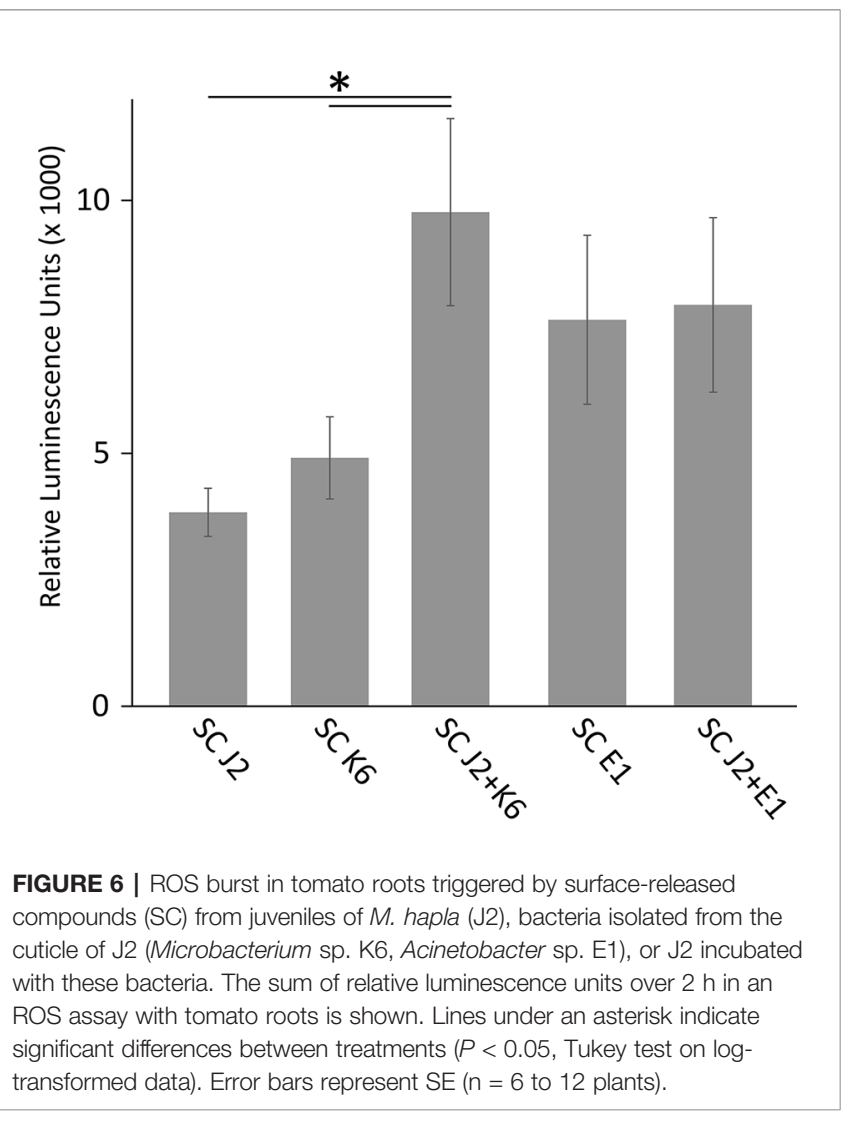

(Adam et al., 2014b; Cao et al., 2015; Elhady et al., 2017; Hussain et al., 2018). Characterization of microbial communities that are in a direct association with plantparasitic nematodes in soil helps deepen the knowledge on the mechanisms that microbes deploy to antagonize these persistent plant parasites. However, previous studies mainly focused on the subtle differences in attached microbiota among different nematode stages or species and in different soils (Adam et al., 2014b; Elhady et al., 2017). Recently, we demonstrated that the soil microbiomes from a glasshouse at Geisenheim University reduced performance of $M$. hapla on tomato plants, while a splitroot experiment revealed the contribution of microbially triggered ISR to this phenomenon (Topalović et al., 2020). In addition, we isolated bacterial strains from the cuticle of $M$. hapla and Pratylenchus penetrans, showing their antagonistic activity, but the ability of nematode-attached bacteria to induce systemic resistance in plants has not yet been investigated (Topalović et al., 2019). Our current study revealed that the early infection of tomato by M. hapla $\mathrm{J} 2$ alone resulted in the suppression of most of the analyzed PTI defense genes, but that the J2-attached microbes either ameliorated this effect, or triggered upregulation of the genes. Plant-parasitic nematodes cause mechanical damage of the host cells, which respond by activating damage-associated molecular pattern triggered defense (Holbein et al., 2016; Shah et al., 2017). The opening wounds can also ease the entrance of pathogenic microorganisms that lead to secondary infections and disease complexes 
(Karimi et al., 2000; Back et al., 2002). However, the RKN are well known to hide themselves from plant recognition, since the J2 move through the apoplast until establishing permanent feeding sites (Sijmons et al., 1994). Notably, it was shown that the cell wall degradation caused by cyst nematodes, while moving through the symplast, trigger activation of polygalacturonase inhibitor proteins (PGIP) in plants, which activate damageassociated molecular pattern triggered defense by production of oligogalacturonides (Benedetti et al., 2015; Shah et al., 2017). In contrast to cyst nematodes, Shah et al. (2017) could not detect activation of PGIP in response to the RKN infection, thus pointing out the ability of RKN to suppress early recognition by the host. In addition, several studies have shown downregulation of PTI-like genes during the early events of RKN infection (Dubreuil et al., 2007; Barcala et al., 2010; Damiani et al., 2012). In our study, J2-attached microbes from the suppressive Geisenheim soil alleviated expression of several PTI-like genes, including GRAS4.1, TFT1, WRKY28, and PDF1.2. Interestingly, the transcription factor TFT1, a marker of JA-mediated PTI, was down-regulated in roots infected with J2. However, the down-regulation of this gene was suppressed by the J2-attached microbes. TFT1 belongs to the tomato 14-3-3 family of acidic, phosphopeptide-binding proteins that are involved in metabolism, signal transduction, transcription, cell cycle, development, apoptosis, and stress signaling (Bridges and Moorhead, 2004; Smith et al., 2011). Taylor et al. (2012) showed that silencing of TFT1 resulted in increased tomato susceptibility to the pathogenic bacterium Xanthomonas campestris pv. vesicatoria, and it was also required for the expression of some other JA- and SA-mediated defense genes, including GRAS and WRKY. The inhibited repression of TFT1 by nematodeassociated microbes in our study suggests that the plant recognized the transmitted microbes upon nematode invasion. The J2-attached microbes from Geisenheim soil also significantly elevated mRNA levels of the transcription factor GRAS4.1. The up-regulation of the GRAS gene was positively correlated with the expression of TFT1 in establishing PTI against X. campestris pv. vesicatoria (Taylor et al., 2012). GRAS transcription factors are involved in plant development, gibberellic acid signaling, symbiotic processes, and stress signaling (Tian et al., 2004). This gene was also up-regulated in tomato and tobacco leaves infected by non-pathogenic Pseudomonas fluorescens as a reporter gene for assaying PTI (Nguyen et al., 2010).

The bacterial strain K6, which belongs to the Gram-positive genus Microbacterium, was previously isolated from the cuticle of M. hapla J2. It was firmly attached to J2, with more than 4,000 $\mathrm{CFU} / \mathrm{J} 2$, and showed antagonistic effects on their viability, movement, and invasion into roots (Topalović et al., 2019). However, plant-mediated effects were more important for its antagonism against $M$. hapla as shown in a split-root experiment (Topalović et al., 2019). Similar to the attachment of microbes from the microbiome of the Geisenheim suppressive soil, the J2attached strain $\mathrm{K} 6$ also ameliorated the J2-induced suppression of defense genes. The expression profiles of the genes differed 1 and $3 \mathrm{dpi}$ in root and leaf tissues. At $1 \mathrm{dpi}$, K6 generally reduced down-regulation of defense genes in roots, while significantly up- regulating $M P K 1$. This effect was stronger 3 dpi with several upregulated genes, including WRKY28, GRAS4.1, and PDF1.2. However, at $1 \mathrm{dpi}$ PTI activation seemed to be limited to belowground tissues as leaves hardly responded to the J2 infection in roots. At $3 \mathrm{dpi}$, K6 had a strong systemic effect in leaves and the defense response in roots increased. A similar pattern of belowground-aboveground response was observed by Wang et al. (2019). They reported root-shoot transmission of electrical and ROS signals in response of Arabidopsis thaliana to Meloidogyne incognita $1 \mathrm{dpi}$. This led to the activation of JA synthesis in leaves. Consecutively, JA systemically triggered the defense in the roots. In our study, the overall low plant responses to $\mathrm{J} 2$ at $1 \mathrm{dpi}$ could also be attributed to the fact that M. hapla J2 are slow invaders in comparison to the more aggressive RKN $M$. incognita. Martínez-Medina et al. (2017a) reported that the fungus T. harzianum T-78 primed local and systemic tomato root tissues during the early stages of $M$. incognita infection by accelerating activation of SA-responsive genes and inhibiting suppression of JA-responsive genes. However, studies on the expression profiles of microbially induced PTI-like genes in roots, in response to nematode infection, are still scarce. It was shown that the expression of SA marker $P R$ genes differed in roots and leaves in response to the RKN, but this seemed to depend on the nematode species and timing (Hamamouch et al., 2011; Dam et al., 2018). Interestingly, the transcription factor WRKY28 was down-regulated in our study in response to both $\mathrm{J} 2$ alone and the J2-attached K6 cells at $1 \mathrm{dpi}$, while it was significantly up-regulated by the K6 cells 3 dpi. Although the RKN cause less damage during the early stages of infection, upregulation of WRKY28 by J2 alone confirms that the RKN $M$. hapla, nevertheless, also induce expression of defense genes (Williamson and Hussey, 1996). The up-regulation of WRKY11 and WRKY17 genes in A. thaliana roots infested with $M$. incognita suggested that these transcription factors behave as positive regulators of plant defense against $\mathrm{RKN}$, as both WRKY11 and WRKY17 mutants showed significantly higher nematode reproduction in comparison to the wild type (Teixeira et al., 2016).

We showed a strong positive correlation between the activation of PTI by J2-attached K6 cells upon nematode penetration and a reduced number of invaded J2 over a 7-day period. Overall, our study suggests that microbes that attach to J2 in soil can antagonize nematodes by ISR in plants. The microbes themselves induced plant responses, so it seems unlikely that the microbial attachment alters the nematode surface, thereby indirectly triggering ISR in the plant. However, this needs further investigations. It has been suggested that the intensity and the duration of ROS burst in plants can determine the compatible or incompatible interaction with RKN (Melillo et al., 2011; Sato et al., 2019). A strong and a prolonged ROS burst caused an incompatible interaction between the plant and RKN, based on an increased plant defense against $\mathrm{J} 2$ penetration (Melillo et al., 2011). In our study, we investigated whether the two M. hapla-isolated bacterial strains, K6 and E1 induce or increase ROS burst in tomato plants exposed to M. hapla J2, and whether the released compounds of the studied organisms 
induced a different reaction. In the ROS assay, the reaction of the plant was 100 times stronger in leaves than in roots. Moreover, the compounds released from the surface of $\mathrm{J} 2$ triggered a ROS burst. Likewise, Mendy et al. (2017) reported a strong induction of ROS burst in response to compounds released by two nematode species, Heterodera schachtii and M. incognita, which was accompanied by the expression of JA biosynthesis and signaling genes during the migratory phase in A. thaliana. In our study, K6 cells and cell-free compounds of both bacteria induced a much stronger ROS burst than the nematodes. Notably, the most prolonged ROS burst was recorded in the presence of compounds from J2 and strain K6 together, which might be evidence that active compounds are formed by an interaction of both organisms, for instance by degradation of the cuticle or J2-induced metabolites of strains K6 and E1.

\section{CONCLUSIONS}

Nematodes encounter a vast number of microorganisms in soil but specifically attach only a few of them (Adam et al., 2014b; Elhady et al., 2017). However, the antagonistic properties of nematode-attached microbes have been hardly investigated, with the exception of Pasteuria endospores. Recently, we have isolated bacterial strains that attached to the cuticle of $\mathrm{J} 2$ of $M$. hapla in different soils and demonstrated their effects against J2 viability and invasion into roots (Topalović et al., 2019). Our current study aimed to investigate whether the nematode-attached microbes can trigger ISR in plants and in this way contribute to soil suppressiveness against M. hapla. The results suggest that the microbes attaching to M. hapla J2 in suppressive Geisenheim soil triggered a differential expression of PTI-responsive genes in tomato roots, $3 \mathrm{dpi}$. In addition, it was also shown that the attachment of Microbacterium sp. K6 to J2 prior to their invasion into the roots induced expression of PTI-like genes in roots and leaves. The attachment of $\mathrm{K} 6$ cells to the J2 significantly reduced the J2 establishment, confirming a plant-mediated antagonistic effect of strain K6 against M. hapla (Topalović et al., 2019). Overall, our data suggest that nematode-attached microbes have a positive role in plant defense against the sedentary endoparasite M. hapla. Our study contributes to the current knowledge on the

\section{REFERENCES}

Adam, M., Heuer, H., and Hallmann, J. (2014a). Bacterial antagonists of fungal pathogens also control root-knot nematodes by induced systemic resistance of tomato plants. PloS One 9, e90402. doi: 10.1371/ journal.pone.0090402

Adam, M., Westphal, A., Hallmann, J., and Heuer, H. (2014b). Specific microbial attachment to root knot nematodes in suppressive soil. Appl. Environ. Microbiol. 80, 2679-2686. doi: 10.1128/AEM.03905-13

Back, M. A., Haydock, P. P. J., and Jenkinson, P. (2002). Disease complexes involving plant parasitic nematodes and soilborne pathogens. Plant Pathol. 51, 683-697. doi: 10.1046/j.1365-3059.2002.00785.x

Bais, H. P., Weir, T. L., Perry, L. G., Gilroy, S., and Vivanco, J. M. (2006). The role of root exudates in rhizosphere interactions with plants and other organisms. Annu. Rev. Plant Biol. 57, 233-266. doi: 10.1146/ annurev.arplant.57.032905.105159 tripartite plant-nematode-microbe interactions in soil and on nematode suppression by microbially induced systemic resistance in plants.

\section{DATA AVAILABILITY STATEMENT}

All datasets generated for this study are included in the article/ Supplementary Material.

\section{AUTHOR CONTRIBUTIONS}

OT did the experiments, contributed to the ideas, and wrote the manuscript. SB and AS designed and performed the ROS assay together with OT. OT and $\mathrm{HH}$ statistically analyzed the data. $\mathrm{HH}$ initiated and supervised the research, and revised the manuscript. All authors read, revised, and approved the final manuscript.

\section{FUNDING}

The study was funded by the German Research Foundation grant DFG HE6957/1-1.

\section{ACKNOWLEDGMENTS}

We thank Dr. Zoran Radaković for his help, Elvira Woldt for excellent technical assistance, and Prof. Annette Reineke for access to the suppressive soil in a greenhouse of the Geisenheim University.

\section{SUPPLEMENTARY MATERIAL}

The Supplementary Material for this article can be found online at: https://www.frontiersin.org/articles/10.3389/fpls.2020.00138/ full\#supplementary-material

Barcala, M., García, A., Cabrera, J., Casson, S., Lindsey, K., Favery, B., et al. (2010) Early transcriptomic events in microdissected Arabidopsis nematode-induced giant cells. Plant J. 61, 698-712. doi: 10.1111/j.1365-313X.2009.04098.x

Benedetti, M., Pontiggia, D., Raggi, S., Cheng, Z., Scaloni, F., Ferrari, S., et al. (2015). Plant immunity triggered by engineered in vivo release of oligogalacturonides, damage-associated molecular patterns. Proc. Natl. Acad. Sci. U.S.A. 112, 5533-5538. doi: 10.1073/pnas.1504154112

Bertin, C., Yang, X., and Weston, L. A. (2003). The role of root exudates and allelochemicals in the rhizosphere. Plant Soil 256, 67-83. doi: 10.1023/ A:1026290508166

Bhattarai, K. K., Xie, Q.-G., Mantelin, S., Bishnoi, U., Girke, T., Navarre, D. A., et al. (2008). Tomato susceptibility to root-knot nematodes requires an intact jasmonic acid signaling pathway. Mol. Plant Microbe Interact. 21, 1205-1214. doi: 10.1094/MPMI-21-9-1205

Bridges, D., and Moorhead, G. B. G. (2004). 14-3-3 proteins: a number of functions for a numbered protein. Sci. STKE 2004, re10. doi: 10.1126/stke.2422004re10 
Campos, M. L., Kang, J.-H., and Howe, G. A. (2014). Jasmonate-triggered plant immunity. J. Chem. Ecol. 40, 657-675. doi: 10.1007/s10886-014-0468-3

Cao, Y., Tian, B., Ji, X., Shang, S., Lu, C., and Zhang, K. (2015). Associated bacteria of different life stages of Meloidogyne incognita using pyrosequencing-based analysis. J. Basic Microbiol. 55, 950-960. doi: 10.1002/jobm.201400816

Coninck, B., Timmermans, P., Vos, C., Cammue, B. P. A., and Kazan, K. (2015). What lies beneath: belowground defense strategies in plants. Trends Plant Sci. 20, 91-101. doi: 10.1016/j.tplants.2014.09.007

Coyne, D. L., Cortada, L., Dalzell, J. J., Claudius-Cole, A. O., Haukeland, S., Luambano, N., et al. (2018). Plant-parasitic nematodes and food security in Sub-Saharan Africa. Annu. Rev. Phytopathol. 56, 381-403. doi: 10.1146/ annurev-phyto-080417-045833

Dababat, A. A., and Sikora, R. A. (2007). Induced resistance by the mutualistic endophyte, Fusarium oxysporum strain 162, toward Meloidogyne incognita on tomato. Biocontrol Sci. Technol. 17, 969-975. doi: 10.1080/09583150701582057

Dam, N.M.v., Wondafrash, M., Mathur, V., and Tytgat, T. O. G. (2018). Differences in hormonal signaling triggered by two root-feeding nematode species result in contrasting effects on aphid population growth. Front. Ecol. Evol. 6, 909. doi: 10.3389/fevo.2018.00088

Damiani, I., Baldacci-Cresp, F., Hopkins, J., Andrio, E., Balzergue, S., Lecomte, P., et al. (2012). Plant genes involved in harbouring symbiotic rhizobia or pathogenic nematodes. New Phytol. 194, 511-522. doi: 10.1111/j.14698137.2011.04046.x

De-la-Peña, C., and Loyola-Vargas, V. M. (2014). Biotic interactions in the rhizosphere: a diverse cooperative enterprise for plant productivity. Plant Physiol. 166, 701-719. doi: 10.1104/pp.114.241810

Doornbos, R. F., van Loon, L. C., Bakker,, and Peter, A. H. M. (2012). Impact of root exudates and plant defense signaling on bacterial communities in the rhizosphere. A review. Agron. Sustain. Dev. 32, 227-243. doi: 10.1007/s13593011-0028-y

Dubreuil, G., Magliano, M., Deleury, E., Abad, P., and Rosso, M. N. (2007). Transcriptome analysis of root-knot nematode functions induced in the early stages of parasitism. New Phytol. 176, 426-436. doi: 10.1111/j.14698137.2007.02181.x

Elhady, A., Giné, A., Topalović, O., Jacquiod, S., Sørensen, S. J., Sorribas, F. J., et al. (2017). Microbiomes associated with infective stages of root-knot and lesion nematodes in soil. PloS One 12, e0177145. doi: 10.1371/journal.pone.0177145

Elhady, A., Adss, S., Hallmann, J., and Heuer, H. (2018). Rhizosphere microbiomes modulated by pre-crops assisted plants in defense against plant-parasitic nematodes. Front. Microbiol. 9, 2679. doi: 10.3389/ fmicb.2018.01133

Gheysen, G., and Mitchum, M. G. (2011). How nematodes manipulate plant development pathways for infection. Curr. Opin. Plant Biol. 14, 415-421. doi: 10.1016/j.pbi.2011.03.012

Hamamouch, N., Li, C., Seo, P. J., Park, C.-M., and Davis, E. L. (2011). Expression of Arabidopsis pathogenesis-related genes during nematode infection. Mol. Plant Pathol. 12, 355-364. doi: 10.1111/j.1364-3703.2010.00675.x

Harel, Y. M., Mehari, Z. H., Rav-David, D., and Elad, Y. (2014). Systemic resistance to gray mold induced in tomato by benzothiadiazole and Trichoderma harzianum T39. Phytopathology 104, 150-157. doi: 10.1094/ PHYTO-02-13-0043-R

Holbein, J., Grundler, F. M. W., and Siddique, S. (2016). Plant basal resistance to nematodes: an update. J. Exp. Bot. 67, 2049-2061. doi: 10.1093/jxb/erw005

Hussain, M., Hamid, M. I., Tian, J., Hu, J., Zhang, X., Chen, J., et al. (2018). Bacterial community assemblages in the rhizosphere soil, root endosphere and cyst of soybean cyst nematode-suppressive soil challenged with nematodes. FEMS Microbiol. Ecol. 94, fiy142. doi: 10.1093/femsec/fiy142

Jones, J. D. G., and Dangl, J. L. (2006). The plant immune system. Nature 444, 323-329. doi: 10.1038/nature05286

Jones, J. T., Haegeman, A., Danchin, E. G. J., Gaur, H. S., Helder, J., Jones, M. G. K., et al. (2013). Top 10 plant-parasitic nematodes in molecular plant pathology. Mol. Plant Pathol. 14, 946-961. doi: 10.1111/mpp.12057

Kandoth, P. K., Ranf, S., Pancholi, S. S., Jayanty, S., Walla, M. D., Miller, W., et al. (2007). Tomato MAPKs LeMPK1, LeMPK2, and LeMPK3 function in the systemin-mediated defense response against herbivorous insects. Proc. Natl. Acad. Sci. U.S.A. 104, 12205-12210. doi: 10.1073/pnas.0700344104

Kang, W., Zhu, X., Wang, Y., Chen, L., and Duan, Y. (2018). Transcriptomic and metabolomic analyses reveal that bacteria promote plant defense during infection of soybean cyst nematode in soybean. BMC Plant Biol. 18, 86. doi: 10.1186/s12870-018-1302-9

Karimi, M., van Montagu, M., and Gheysen, G. (2000). Nematodes as vectors to introduce Agrobacterium into plant roots. Mol. Plant Pathol. 1, 383-387. doi: 10.1046/j.1364-3703.2000.00043.x

Lamb, C., and Dixon, R. A. (1997). The oxidative burst in plant disease resistance. Annu. Rev. Plant Physiol. Plant Mol. Biol. 48, 251-275. doi: 10.1146/ annurev.arplant.48.1.251

Ma, H.-K., Pineda, A., van der Wurff, A. W. G., Raaijmakers, C., and Bezemer, T. M. (2017). Plant-soil feedback effects on growth, defense and susceptibility to a soilborne disease in a cut flower crop: species and functional group effects. Front. Plant Sci. 8, 2127. doi: 10.3389/fpls.2017.02127

Martínez-Medina, A., Fernández, I., Sánchez-Guzmán, M. J., Jung, S. C., Pascual, J. A., and Pozo, M. J. (2013). Deciphering the hormonal signalling network behind the systemic resistance induced by Trichoderma harzianum in tomato. Front. Plant Sci. 4, 206. doi: 10.3389/fpls.2013.00206

Martínez-Medina, A., Fernández, I., Lok, G. B., Pozo, M. J., Pieterse, C. M. J., Wees, S. C. M., et al. (2017a). Shifting from priming of salicylic acid- to jasmonic acid-regulated defences by Trichoderma protects tomato against the root knot nematode Meloidogyne incognita. New Phytol. 213, 1363-1377. doi: $10.1111 /$ nph.14251

Martínez-Medina, A., Wees, S. C. M., Van, Pieterse, C. M. J., Wees, S. C. M., and Van, (2017b). Airborne signals by Trichoderma fungi stimulate iron uptake responses in roots resulting in priming of jasmonic acid-dependent defences in shoots of Arabidopsis thaliana and Solanum lycopersicum. Plant Cell Environ. 40, 2691-2705. doi: 10.1111/pce.13016

Melillo, M. T., Leonetti, P., Leone, A., Veronico, P., and Bleve-Zacheo, T. (2011). ROS and NO production in compatible and incompatible tomato-Meloidogyne incognita interactions. Eur. J. Plant Pathol. 130, 489-502. doi: 10.1007/s10658011-9768-4

Mendy, B., Wang'ombe, M. W., Radakovic, Z. S., Holbein, J., Ilyas, M., Chopra, D., et al. (2017). Arabidopsis leucine-rich repeat receptor-like kinase NILR1 is required for induction of innate immunity to parasitic nematodes. PloS Pathog. 13, e1006284. doi: 10.1371/journal.ppat.1006284

Millet, Y. A., Danna, C. H., Clay, N. K., Songnuan, W., Simon, M. D., WerckReichhart, D., et al. (2010). Innate immune responses activated in Arabidopsis roots by microbe-associated molecular patterns. Plant Cell 22, 973-990. doi: 10.1105/tpc.109.069658

Munif, A., Hallmann, J., and Sikora, R. A. (2001). Induced systemic resistance of selected endophytic bacteria against Meloidogyne incognita on tomato. Med. Fac. Landbouww. Univ. Gent. 66, 663-669.

Nguyen, H. P., Chakravarthy, S., Velásquez, A. C., McLane, H. L., Zeng, L., Nakayashiki, H., et al. (2010). Methods to study PAMP-triggered immunity using tomato and Nicotiana benthamiana. Mol. Plant Microbe Interact. 23, 991-999. doi: 10.1094/MPMI-23-8-0991

Pfaffl, M. W. (2001). A new mathematical model for relative quantification in realtime RT-PCR. Nucleic Acids Res. 29, 45e-445. doi: 10.1093/nar/29.9.e45

Pieterse, C. M. J., Does, D., Van der, Zamioudis, C., Leon-Reyes, A., Wees, S. C. M., et al. (2012). Hormonal modulation of plant immunity. Annu. Rev. Cell Dev. Biol. 28, 489-521. doi: 10.1146/annurev-cellbio-092910-154055

Prince, D. C., Drurey, C., Zipfel, C., and Hogenhout, S. A. (2014). The leucine-rich repeat receptor-like kinase BRASSINOSTEROID INSENSITIVE1ASSOCIATEDKINASE and the cytochrome P450 PHYTOALEXIN DEFICIENT3 contribute to innate immunity to aphids in Arabidopsis. Plant Physiol. 164, 2207-2219. doi: 10.1104/pp.114.235598

Reitz, M., Rudolph, K., Schröder, I., Hoffmann-Hergarten, S., Hallmann, J., and Sikora, R. A. (2000). Lipopolysaccharides of Rhizobium etli strain G12 act in potato roots as an inducing agent of systemic resistance to infection by the cyst nematode Globodera pallida. Appl. Environ. Microbiol. 66, 3515-3518. doi: 10.1128/AEM.66.8.3515-3518.2000

Sato, K., Kadota, Y., and Shirasu, K. (2019). Plant immune responses to parasitic nematodes. Front. Plant Sci. 10, 163. doi: 10.3389/fpls.2019.01165

Selim, M. E., Mahdy, M. E., Sorial, M. E., Dababat, A. A., and Sikora, R. A. (2014). Biological and chemical dependent systemic resistance and their significance for the control of root-knot nematodes. Nematol 16, 917-927. doi: 10.1163/ 15685411-00002818

Shah, S. J., Anjam, M. S., Mendy, B., Anwer, M. A., Habash, S. S., LozanoTorres, J. L., et al. (2017). Damage-associated responses of the host 
contribute to defence against cyst nematodes but not root-knot nematodes. J. Exp. Bot. 68, 5949-5960. doi: 10.1093/jxb/erx374

Siddique, S., and Grundler, F. M. W. (2018). Parasitic nematodes manipulate plant development to establish feeding sites. Curr. Opin. Microbiol. 46, 102108. doi: 10.1016/j.mib.2018.09.004

Siddiqui, I. A., and Shaukat, S. S. (2004). Systemic resistance in tomato induced by biocontrol bacteria against the root-knot nematode, Meloidogyne javanica is independent of salicylic acid production. J. Phytopathol. 152, 48-54. doi: 10.1046/ j.1439-0434.2003.00800.x

Sijmons, P. C., Grundler, F. M. W., Mende, N., Burrows, P. R., and Wyss, U. (1991). Arabidopsis thaliana as a new model host for plant-parasitic nematodes. Plant J. 1, 245-254. doi: 10.1111/j.1365-313X.1991.00245.x

Sijmons, P. C., Atkinson, H. J., and Wyss, U. (1994). Parasitic strategies of root nematodes and associated host cell responses. Annu. Rev. Phytopathol. 32, 235-259. doi: 10.1146/annurev.py.32.090194.001315

Silva, J.C.P.d., Medeiros, F.H.V.d., and Campos, V. P. (2018). Building soil suppressiveness against plant-parasitic nematodes. Biocontrol Sci. Technol. 28, 423-445. doi: 10.1080/09583157.2018.1460316

Smith, A. J., Daut, J., and Schwappach, B. (2011). Membrane proteins as 14-3-3 clients in functional regulation and intracellular transport. Physiology (Bethesda) 26, 181-191. doi: 10.1152/physiol.00042.2010

Taylor, K. W., Kim, J.-G., Su, X. B., Aakre, C. D., Roden, J. A., Adams, C. M., et al. (2012). Tomato TFT1 is required for PAMP-triggered immunity and mutations that prevent T3S effector XopN from binding to TFT1 attenuate Xanthomonas virulence. PloS Pathog. 8, e1002768. doi: 10.1371/ journal.ppat. 1002768

Teixeira, M. A., Wei, L., and Kaloshian, I. (2016). Root-knot nematodes induce pattern-triggered immunity in Arabidopsis thaliana roots. New Phytol. 211, 276-287. doi: 10.1111/nph.13893

Tian, C., Wan, P., Sun, S., Li, J., and Chen, M. (2004). Genome-wide analysis of the GRAS gene family in rice and Arabidopsis. Plant Mol. Biol. 54, 519-532. doi: 10.1023/B:PLAN.0000038256.89809.57

Topalović, O., and Heuer, H. (2019). Plant-nematode interactions assisted by microbes in the rhizosphere. Curr. Issues Mol. Biol. 30, 75-88. doi: 10.21775/ cimb.030.075
Topalović, O., Elhady, A., Hallmann, J., Richert-Pöggeler, K. R., and Heuer, H. (2019). Bacteria isolated from the cuticle of plant-parasitic nematodes attached to and antagonized the root-knot nematode Meloidogyne hapla. Sci. Rep. 9, 11477. doi: 10.1038/s41598-019-47942-7

Topalović, O., Heuer, H., Reineke, A., Zinkernagel, J., and Hallmann, J. (2020). Antagonistic role of the microbiome from a Meloidogyne haplasuppressive soil against species of plant-parasitic nematodes with different life strategies. Nematol. 22, 75-86. doi: 10.1163/1568541100003285

Tran, T., Chen, S., and Wang, X. (2017). Root assays to study pattern-triggered immunity in plant-nematode interactions. Eur. J. Plant Pathol. 147, 955-961. doi: 10.1007/s10658-016-1053-0

Wang, G., Hu, C., Zhou, J., Liu, Y., Cai, J., Pan, C., et al. (2019). Systemic rootshoot signaling drives jasmonate-based root defense against nematodes. Curr. Biol. 29, 3430-3438. doi: 10.1016/j.cub.2019.08.049

Wees, S. C. M., Van, van der Ent, S., and Pieterse, C. M. J. (2008). Plant immune responses triggered by beneficial microbes. Curr. Opin. Plant Biol. 11, 443-448. doi: 10.1016/j.pbi.2008.05.005

Williamson, V. M., and Hussey, R. S. (1996). Nematode pathogenesis and resistance in plants. Plant Cell 8, 1735-1745. doi: 10.1105/tpc.8. 10.1735

$\mathrm{Wu}$ J., and Baldwin, I. T. (2010). New insights into plant responses to the attack from insect herbivores. Annu. Rev. Genet. 44, 1-24. doi: 10.1146/annurevgenet-102209-163500

Conflict of Interest: The authors declare that the research was conducted in the absence of any commercial or financial relationships that could be construed as a potential conflict of interest.

Copyright $\odot 2020$ Topalović, Bredenbruch, Schleker and Heuer. This is an open-access article distributed under the terms of the Creative Commons Attribution License (CC $B Y)$. The use, distribution or reproduction in other forums is permitted, provided the original author(s) and the copyright owner(s) are credited and that the original publication in this journal is cited, in accordance with accepted academic practice. No use, distribution or reproduction is permitted which does not comply with these terms. 